\title{
Correlation for the Lower Palaeozoic
}

\author{
L. ROBIN M. COCKS*, RICHARD A. FORTEY \& ADRIAN W. A. RUSHTON \\ Department of Palaeontology, The Natural History Museum, Cromwell Road, London SW7 5BD, UK
}

(Received 24 February 2009; accepted 13 July 2009; First published online 14 September 2009)

\begin{abstract}
The global correlation standards now agreed for the Ordovician and Silurian systems, and partly so for the Cambrian System, are summarized. Correlation of the international series and stages with the traditional and revised British series and stages is reviewed, as well as with those in North America (Laurentia).
\end{abstract}

Keywords: Cambrian, Ordovician, Silurian, correlation, British Isles.

\section{Introduction}

For more than fifty years, the stratigraphical community has been progressing, albeit slowly, towards an agreed global standard accepted by the IUGS International Commission on Stratigraphy by which to correlate the Lower Palaeozoic. Since this protracted process is now largely complete for the Ordovician and Silurian and partially finished for the Cambrian, it seems timely to communicate that standard more widely and show how it relates to the British terms which have been well known and much used internationally for the best part of two centuries.

Thus we have constructed Figure 1 to include the new global standard; the British regional units which form the basis for the revised Ordovician (Fortey et al. 2000) and Silurian (Cocks, Holland \& Rickards, 1992) correlation charts; the earlier Geological Society correlation charts (Cocks et al. 1971; Williams et al. 1972; Cowie, Rushton \& Stubblefield, 1972); and the column used locally in North America for Laurentia, all calibrated against real ages. Those radiometric ages come from a variety of sources not reviewed here, and have been rounded to the nearest one million years, which we feel is appropriate for rocks of these periods in view of the margins of error usually involved, but Sadler, Cooper \& Melchin (2009) have published useful ages and graptolite and conodont zones for the Ordovician and Silurian. We have concentrated on the final global stratigraphical decisions reached and how they correlate with the older framework used in the British Isles (including Ireland) and the Laurentian part of North America, rather than dwelling in detail on how those decisions were made, which are the topics of many substantial publications.

The divisions will now be reviewed briefly in turn. Not all are classified at the same level in stratigraphical terminology: some are series and some stages, but we present them as ratified by the International Commission on Stratigraphy. The four official series within the Cambrian range from the Terreneuvian to the Furongian; it is proposed that they should be divided

*Author for correspondence: r.cocks@nhm.ac.uk into ten stages (Fig. 1), some of which are named. There are no formal Lower, Middle and Upper subdivisions of the Cambrian. In contrast, the Ordovician is divided into three series, the Lower to include the Tremadocian and Floian stages, the Middle to include the Dapingian and Darriwilian, and the Upper Series to include the Sandbian, Katian and Hirnantian stages. The Silurian is in theory formally divided into the Lower Silurian Subsystem to include the Llandovery Series and the Wenlock Series and the Upper Silurian to include the Ludlow Series and the Pridoli Series; however, since it is now known that the Llandovery alone lasted for more than half of Silurian time, we do not favour the use of those terms.

\section{The Precambrian-Cambrian boundary}

In the nineteenth century neither Sedgwick nor Murchison gave precise definitions of the base of the Cambrian; for the next hundred years, before reliable radiometric dating and during which stratigraphical correlation depended on biostratigraphy, the virtually unfossiliferous Precambrian rocks were poorly correlated. The base of the Cambrian was reviewed in a major symposium (Rodgers, 1956) and, after much debate, it was stabilized at Fortune Head, southeast Newfoundland, Canada. The basal stratotype (GSSP) there, proposed by Narbonne et al. (1987), is at the first occurrence of the trace fossil Phycodes (now Treptichnus) pedum $2.4 \mathrm{~m}$ above the base of Member 2 of the Chapel Island Formation (Brasier, Cowie \& Taylor, 1994). That horizon, which has been radiometrically dated at $543 \mathrm{Ma}$ (Grotzinger et al. 1995), is at a lower level than the bases of most of the rocks previously considered Lower Cambrian in the British Isles.

\section{The Cambrian System}

Although originally named by Sedgwick (in Sedgwick \& Murchison, 1835) for an assemblage of fossiliferous rocks below the Silurian, the Cambrian System only reached something like its present definition when 


\begin{tabular}{|c|c|c|c|c|c|c|c|c|}
\hline \multirow{3}{*}{\begin{tabular}{|c|}
$\mathbf{M a}$ \\
410 \\
\end{tabular}} & \multicolumn{3}{|c|}{ Global standard } & \multicolumn{2}{|c|}{ British regional } & \multicolumn{2}{|c|}{$\begin{array}{c}\text { Geological Society } \\
1971-1972 \\
\end{array}$} & \multirow[t]{2}{*}{ North America } \\
\hline & \multirow{2}{*}{$\overrightarrow{\mathrm{u}}$} & \multirow{2}{*}{\multicolumn{2}{|c|}{$\begin{array}{c}\text { Pragian } \\
\text { Lochkovian }\end{array}$}} & & & \multirow{2}{*}{ 窝 } & & \\
\hline & & & & & & & Ditton & Helderbergian \\
\hline \multirow{3}{*}{$420-$} & \multirow{6}{*}{ 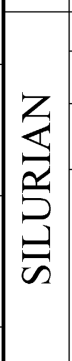 } & \multirow{2}{*}{\multicolumn{2}{|c|}{$\begin{array}{l}\text { Pridoli } \\
\text { Ludlow }\end{array}$}} & Pridoli & Downtonian & \multirow{6}{*}{ 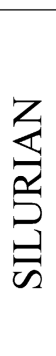 } & Downton & Pridoli \\
\hline & & & & Ludlow & $\begin{array}{l}\text { Ludfordian } \\
\text { Gorstian } \\
\end{array}$ & & Ludlow & Ludlow \\
\hline & & Wenlo & ock & Wenlock & $\begin{array}{c}\text { Homerian } \\
\text { Sheinwoodian }\end{array}$ & & Wenlock & Wenlock \\
\hline $430-$ & & \multirow{3}{*}{\multicolumn{2}{|c|}{ Llandovery }} & \multirow[t]{3}{*}{ Llandovery } & Telychian & & \multirow{3}{*}{ Llandovery } & \multirow[t]{3}{*}{ Llandovery } \\
\hline \multirow{3}{*}{$440-$} & & & & & Aeronian & & & \\
\hline & & & & & Rhuddanian & & & \\
\hline & \multirow{8}{*}{$\begin{array}{l}z \\
\leq \\
0 \\
z \\
0 \\
\text { ح̂. } \\
0\end{array}$} & \multicolumn{2}{|c|}{ Hirnantian } & \multirow{2}{*}{ Ashgill } & $\begin{aligned} & \text { Hirnantian } \\
& \text { Rànthe-yan-- }\end{aligned}$ & \multirow{8}{*}{ 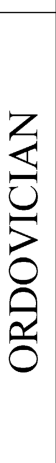 } & \multirow{2}{*}{ Ashgill } & \multirow{2}{*}{ Cincinnatian } \\
\hline \multirow[t]{2}{*}{$450-$} & & \multirow{2}{*}{\multicolumn{2}{|c|}{ Katian }} & & $\begin{array}{c}\text { Cautlevan } \\
\text { Pussillian } \\
\text { Sufforion }\end{array}$ & & & \\
\hline & & & & \multirow{2}{*}{ Caradoc } & Cheneyan & & \multirow{2}{*}{ Caradoc } & Mohawkian \\
\hline \multirow{5}{*}{$460-$} & & \multicolumn{2}{|c|}{ Sandbian } & & $\begin{array}{l}\text { Burrellian } \\
\text { Aurelucian }\end{array}$ & & & \\
\hline & & Darriwi & ilian & Llanvirn & $\begin{array}{l}\text { Llandeilian } \\
\text { Abereiddian } \\
\end{array}$ & & $\begin{array}{l}\text { Llandeilo } \\
\text { Llanvirn }\end{array}$ & Whiterockian \\
\hline & & Daping & gian & & Fennian & & & \\
\hline & & & & Arenig & Whitlandian & & Arenig & \\
\hline & & Floia & & & Moridunian & & & \\
\hline $480-$ & & Tremadd & & & Migneintian & & & Ibexian \\
\hline & & Tremado & ocian & Tremadoc & Cressagian & & Tremadoc & \\
\hline $490-$ & & & Stage 10 & & & & & \\
\hline & & Furongian & \begin{tabular}{|l|} 
Stage 9 \\
\end{tabular} & Merioneth & & & Merioneth & Sunwaptan \\
\hline & & & Paibian & & & Z & & Steptoean \\
\hline $500^{-}$ & & & Guzhangian & & & $\vec{x}$ & & Marjuman \\
\hline & Z & Series 3 & \begin{tabular}{|l|} 
Drumian \\
Stage 5 \\
\end{tabular} & St David's & & $\sum$ & St David's & Delameran \\
\hline $510-$ & $\mathbb{\Omega}$ & & Stage 4 & & [no stages & $\mathbb{U}$ & & Dyerian \\
\hline 520 & $\sum^{\bullet}$ & Series 2 & Stage 3 & Comley & in use] & & & Montezuman \\
\hline & 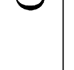 & & Stage 2 & & & & & \\
\hline $530-$ & & Terreneuvian & Fortunian & & & 文 & & [unnamed] \\
\hline $540-$ & & & & Precambrian & & $\sum$ & & \\
\hline & $\begin{array}{l}\Psi \\
1 \\
\rho_{1}^{\prime}\end{array}$ & Ediaca & $\operatorname{aran}$ & & & 足 & & Precambrian \\
\hline
\end{tabular}

Figure 1. Correlation chart for the Lower Palaeozoic, showing ages in millions of years (Ma); the global standard divisions; the British regional subdivisions, modified from Cowie, Rushton \& Stubblefield (1972) for the Cambrian, Fortey et al. (2000) for the Ordovician, and Cocks, Holland \& Rickards (1992) for the Silurian; the subdivisions previously published by The Geological Society of London (Cowie, Rushton \& Stubblefield, 1972; Williams et al. 1972; Cocks et al. 1971); and the units used locally in Laurentia.

Lapworth (1879) published his paper that erected the Ordovician. Recently, the global division of the Cambrian into Lower, Middle and Upper units has been replaced by recognition of four series and (provisionally) ten stages, but at present only half of these divisions are formally named. Figure 1 shows a tentative correlation of this incomplete standard with the six named stages of the Laurentian Cambrian, as summarized by Palmer (1998). These divisions are intended to facilitate correlation across the Laurentian Craton from its interior to the edge of the shelf, and their recognition exploits mass extinction events, 
particularly of endemic trilobites. In contrast, the international standard has drawn mostly on shelf-edge faunas, since they tend to be more widely dispersed over several terranes.

\section{3.a. Terreneuvian Series and Fortunian Stage}

The base of both series and stage is the same as the base of the Cambrian System, as defined in Newfoundland (Landing et al. 2007; Section 2, above). Some strata in Britain that are now correlated with the earliest Cambrian were until recently regarded as late Precambrian (McIlroy, Brasier \& Moseley, 1998).

\section{3.a.1. Stage 2}

Stage 2 of the Cambrian is not yet defined or named, but the level at which its base will be taken is likely to be governed by consideration of archaeocyathid zones and/or the distribution of 'small shelly fossils' (or 'SSF', a variety of sclerites, many from animals of debated zoological affinity), supported by other criteria (Babcock et al. 2005, p. 103). Figure 1 arbitrarily shows the base of the Comley Series extending down into Stage 2.

\section{3.b. Series 2}

Series 2 (and the concomitant base of Stage 3) is not yet defined, but the appearance of the earliest trilobites is expected to be a significant criterion in formalizing its definition (Babcock et al. 2005, p. 103); however, other correlative criteria will be critical in recognizing Series 2. While the definition of Stage 3 is pending, it is impossible to point to definite equivalents in Britain. The Montezuman Stage in Laurentia is similarly based on the earliest trilobites there, and its base is tentatively aligned with the base of Series 2 in Figure 1.

\section{3.b.1. Stage 4}

The base of Stage 4 will likely be defined by reference to the first appearance of a trilobite, possibly a redlichiid or olenellid (Babcock et al. 2005), supported by other criteria. It is expected that, when defined, it will be possible to relate such a base to the appearance in Britain of the olenelloid trilobite Callavia (Fletcher, 2006). In Britain this is near a level at the top of the Lower Comley Sandstone at Comley, Shropshire. However, it is yet to be determined how that level will correlate with the base of the Dyerian stage in Laurentia.

\section{3.c. Series 3}

Although the congruent bases of Series 3 and Stage 5 are not yet agreed, a range of possible levels, based on various criteria, has been discussed (Geyer, 2005). Even the youngest of these proposed levels is older than the base of the St David's Series as originally described by Cowie, Rushton \& Stubblefield (1972), and the older horizons are well down within the Comley Series.

\section{3.c.1. Drumian Stage}

The base is taken at the appearance of the agnostoid Acidusus (or Ptychagnostus) atavus in the base of a limestone layer $62 \mathrm{~m}$ above the base of the Wheeler Formation at Stratotype Ridge in the Drum Mountains, Utah, USA (Babcock et al. 2007). The most general use of the old British term Menevian corresponds fairly closely with the Drumian.

\section{3.c.2. Guzhangian Stage}

The base of this, the seventh stage of the Cambrian, is taken at the appearance of the agnostoid Lejopyge laevigata $121.3 \mathrm{~m}$ above the base of the Huaqiao Formation in the Luoyixi section in Guzhang County, Hunan Province, China. In Britain, the Guzhangian spans a widespread hiatus in the upper part of the St David's Series and extends up into the basal zone of the Merioneth Series of Cowie, Rushton \& Stubblefield (1972). The Laurentian Marjumian Stage extends from below the base of the Drumian up to the base of the Furongian Series.

\section{3.d. Furongian Series}

This series extends up to the base of the Ordovician. Its base, and that of the Paibian Stage, is taken at the appearance of the distinctive and widespread agnostoid Glyptagnostus reticulatus at a level $396 \mathrm{~m}$ above the base of the Huaqiao Formation in the section at Paibi, Huayuan County, NW Hunan (Peng et al. 2004a,b). In Britain this corresponds closely to the base of the Olenus trilobite zone (Rushton, 1983). Thus the Furongian corresponds to the Merioneth Series, but excluding its basal Agnostus pisiformis Zone, and the Paibian roughly to the old term Maentwrog (or Maentwrogian) Stage of many authors (e.g. Harland et al. 1990; Orłowski, 1992). The Laurentian Steptoean Stage correlates closely with the Paibian, but the correlation of its upper limit will depend on the eventual definition of Stage 9.

\section{3.d.1. Stage 9}

The formal definition of the middle stage of the Furongian is expected to be dependent on the appearance of the agnostoid Agnostotes orientalis and/or the elviniid trilobite Irvingella major (Babcock et al. 2005, p. 104). In Britain these may correspond to a level close to the base of the Parabolina spinulosa Zone, and roughly to the base of the inadequately-defined 'Dolgellian' Stage of Harland et al. (1990). The Sunwaptan stage of Laurentia has its base at the Irvingella major Zone and ranges up through part of Stage 10. 


\section{3.d.2. Stage 10}

This is not yet defined, but Babcock et al. (2005, p. 104) suggested that the base might be taken at the appearance of the widespread agnostoid Lotagnostus americanus, which includes among its synonyms $L$. trisectus (Salter), a species recorded from the upper parts of the Dolgellau Formation in North Wales and in equivalent strata elsewhere in Wales and England. The base of the North American Ibexian Series occurs within the upper part of Stage 10.

\section{The Cambro-Ordovician boundary}

Lapworth (1879) defined the base of the Ordovician as at 'the base of the Arenig', but unfortunately that was not crisply delineated except as an unconformity at the base of transgressive sandstones such as the Garth Grit Member in North Wales (Howells \& Smith, 1997). International opinion has varied as to the level of the boundary, and in particular, whether or not the Tremadoc or Tremadocian Stage should be included within the Cambrian or the Ordovician; for example, the Geological Society of London decided some years ago (Fig. 1) to place it within the Cambrian (Cowie, Rushton \& Stubblefield, 1972; Williams et al. 1972). That stage is now within the Ordovician; however, although the Welsh name has been retained, its base has been transferred to a slightly different level defined in Newfoundland (see below).

\section{The Ordovician System}

Lapworth (1879) created the system to include the upper part of Sedgwick's Cambrian and the lower part of Murchison's Silurian, but, although its original top at the base of the Llandovery has been approximately retained, Lapworth's original base has now been extended downward to include the old Tremadoc. All the global stages listed below have been defined in the past ten years; some are defined by graptolites and others by conodonts. Our concern here is principally to relate the classical usage of Ordovician subdivisions based on British type localities to the new international classification. There is no reason why the refined British subdivisions used in the revised Correlation Chart of the Ordovician System in the British Isles (Fortey et al. 2000) should not continue in use for Avalonian and Gondwanan stratigraphy, although the traditional use of five 'series' must be abandoned in favour of the standardized three series (Lower, Middle and Upper Ordovician) as specified by the International Commission on Stratigraphy. The former British 'series' will henceforth be considered as regional stages, and the former stages might be used as regional substages. The correlation between the different schemes runs into trouble only in the midpart of the Ordovician, where the later Arenig and Llanvirn do not bear much resemblance to the new stages spanning that part of the system. 5.a. Base of the Ordovician, the Tremadocian Stage and the Lower Ordovician Series

After nearly twenty years work by a Working Group of the IGCP on the Cambrian-Ordovician boundary, the GSSP for its base and that of the Ordovician System is defined by the lowest occurrence of the conodont Iapetognathus fluctivagus, just above the base of the lindstromi conodont Biozone within Bed 23 of the Green Point Formation at Green Point, western Newfoundland, Canada. Although the appearance of a conodont species is used for the formal definition of the boundary, the appearance of the oldest planktonic graptolites belonging to the Rhabdinopora (formerly Dictyonema) flabelliformis species group is very close to, but not exactly coincident with, the same horizon. This is fortunate for international correlation because many parts of the world lack conodont-yielding limestones, especially in those areas of high Ordovician palaeolatitudes on Gondwana. Thus the appearance of these distinctive graptolites is a de facto boundary marker in many sections and maps in Europe, North Africa and South America, and is easily recognized in the field. In North Wales, the most complete fossiliferous section spanning the Cambrian-Ordovician boundary was described by Rushton (1982), and may be taken as the reference in the historical type area for the Ordovician. This area is also of importance in geochronology because interbedded ashes very close to the base of the Ordovician have yielded a zircon age of $489 \mathrm{Ma}$ (Landing et al. 2000).

The modern meaning of Tremadocian corresponds closely with its traditional usage, but does not equate exactly with the usual definition of the Ordovician Ibexian (quondam Canadian) Series of North America. Intercalation of conodonts, graptolites and trilobites in off-shelf strata in the western USA and China indicates that the base of the ratified Tremadocian lies above the base of the Ibexian as drawn at the base of the Skullrockian Stage in the Great Basin (Miller et al. 2003).

\section{5.b. Floian Stage}

The base of the stage is at the bottom of the approximatus graptolite Biozone at the GSSP at Diabasbrottet, near Flo, Sweden (Bergström, Löfgren \& Maletz, 2004). This corresponds closely with the base of the British Arenig Series as revised by Fortey et al. (1995). However, not all of the old Arenig Series is embraced by the Floian Stage, and the succeeding Dapingian would also have been considered later or upper Arenig in the old sense. The defining basal horizon of the Floian is the first appearance of the widespread and distinctive graptolite Tetragraptus (Etagaptus) approximatus, which has a broad distribution within the Ordovician equatorial region in marine shale basins. It follows upon a distinctive, equally widespread late Tremadocian graptolite assemblage typified by Araneograptus murrayi. Tetragraptus (E.) approximatus did 
not, however, extend into platform successions, such as carbonate platforms, nor did it extend into the high palaeolatitudes such as typified western Ordovician Gondwana. However, it has been recognized for some time that a distinctive acritarch 'flora' known as the messaoudensis-trifidum assemblage acts as a useful surrogate for the basal horizon of the Floian stage, as reviewed in Molyneux, Raevskaya \& Servais (2007), in what were cool water, higher-latitude localities where Floian strata lack distinctive graptolites. Correlation into the limestone successions of Laurentia is difficult, but the base of the Floian is probably close to the base of the Tulean Stage of the Ibexian Series (Ross et al. 1997).

\section{5.c. Dapingian Stage and the Middle Ordovician}

The base is defined at the base of the Baltoniodus triangularis conodont Biozone within the Dawan Formation at Huanghuachang, western Hubei Province, China (Wang et al. 2005). This has brought a conclusion to a long-standing debate about the definition of the Middle Ordovician, which had been used in different senses in different regions of the world for many years. In Europe the Middle Ordovician had been regarded as commencing with the Llanvirn Series in the classical usage, and in Laurentia at the Whiterockian, which is older, although there was confusion about the correlation of its type section in Whiterock Canyon, Nevada, with deeper water graptolitic successions. Unfortunately, the base of the Dapingian does not have a simple relationship with the British standard, and falls within the upper part of the Arenig 'series' of traditional usage. Because $B$. triangularis does not appear in the thick clastic succession attributed to the Arenig in the type Welsh areas (e.g. Fortey \& Owens, 1987), the recognition of the base of the Middle Ordovician requires indirect evidence. Cooper, Crowley \& Rushton (2008) recorded Isograptus victoriae lunatus, which they took as basal Middle Ordovician, from just above a volcanic rock whose age is $473 \mathrm{Ma}$. However, if Stouge et al. (2008) are correct on the basis of graphical correlation in inferring that the appearance of $B$. triangularis 'matches with the first appearance of Isograptus victoriae victoriae' (which succeeds lunatus), then this would be a useful graptolite to use as a surrogate marker fossil since it has been recognized in the Lake District in Britain in strata underlying the Isograptus gibberulus Biozone (Rushton in Cooper et al. 2004). The victoriae Biozone is correlated with the lower part of the Fennian (local) substage in South Wales (Cooper et al. 2004, p. 8). The appearance of $I$. victoriae approximately coincides with that of the long-ranging, and very widespread graptolite Pseudotrigonograptus ensiformis, which is known from the rushtoni Biozone of the Fennian, and its range overlaps with the very widespread species Xiphographus svalbardensis, a species also known from the early Whiterockian of Laurentia. Refinement of the definition of Whiterockian may permit its base to equate with the Dapingian. In summary, the base of the Dapingian and of the Middle Ordovician falls within the upper part of the Arenig 'series' of former usage, and the Dapingian may informally be thought of as 'late Arenig'. The base of the series probably lies close to that of the Fennian, but precise correlation is not resolved.

\section{5.d. Darriwilian Stage}

The base is defined $22 \mathrm{~m}$ below the top of the Ningkuo Formation at Huangnitang, Zhejiang Province, China, at the base of the austrodentatus graptolite Biozone (Chen \& Bergström, 1995). This was the first of the new Ordovician stages to be defined, and the eponymous graptolite Undulograptus austrodentatus (which is an early, but not the earliest biserial form) is remarkably widespread on all Ordovician palaeocontinents. Its appearance in various European sections always shortly precedes the appearance of numerous graptolites of the traditional Llanvirn 'series' including the wellknown 'tuning forks' of the Didymograptus artus species group, varied glossograptids and others. The Darriwilian includes the uppermost part of the former Arenig 'series', together with the classical Llanvirn and Llandeilo 'series'. Fortey et al. (1995) had already acknowledged the brevity of the Llandeilo 'series' and had amalgamated it with an extended Llanvirn 'series'; both now pass into the Darriwilian. The base of the traditional Llanvirn 'series' was recognized by Nielsen (2004) as a widespread maximum flooding surface, and is therefore likely to retain its utility in international correlation.

\section{5.e. Sandbian Stage and Upper Ordovician}

The base is defined at the base of the gracilis graptolite Biozone at Fågelsång, near Sandby in southern Sweden (Bergström et al. 2000). The first appearance of the graptolite Nemagraptus gracilis has been recognized as a biostratigraphical event of global significance ever since the time of Elles (1922). As a name, the Sandbian Stage was preferred by the Ordovician Subcommission over the Caradocian, which has had a long history, and which had also been redefined as commencing at the base of the $N$. gracilis Biozone following the revision of Fortey et al. (2000). This horizon poses relatively few problems for international correlation, and is at a convenient level. However, there is some evidence from graphic correlation that the first appearance of Nemagraptus gracilis itself can be regionally diachronous (Bettley, Fortey \& Siveter, 2001).

\section{5.f. Katian Stage}

The base is at the bottom of the caudatus graptolite Biozone at Black Knob Ridge, 7 km northeast of Atoka in southeastern Oklahoma, USA (Goldman et al. 2007). This horizon has been recognized in the Hartfell Shales 
of Scotland (Zalasiewicz, Rushton \& Owen, 1995) and in central Wales, and thus can be approximately correlated with the type British sequence at or near the base of the Cheneyan Stage. As a result, the Katian appears long, equating to the upper half of the Caradoc as well as more than half of the Ashgill in Britain.

\section{5.g. Hirnantian Stage}

The base is defined at the base of the extraordinarius graptolite Biozone within the Wufeng Formation at Wangjiawan North section, western Hubei Province, China. Although of short duration, the Hirnantian is widely recognized as coinciding with a globally important glaciation, accompanied by a major mass extinction. Because of the pervasive nature of this event, most rock sections spanning the Hirnantian are dominated by glacial influence (and this includes the British section which gives it its name); hence the preferred GSSP in a deeper water succession at a relatively low palaeolatitude. The stage is marked also by isotopic excursions, and by characteristic shelf 'crisis' fossil faunas, which makes it comparatively easy to recognize on a global basis. It is essentially the same as the Hirnantian Stage, which has been used in Britain for some time (references in Fortey et al. 2000).

\section{The Ordovician-Silurian boundary}

Lapworth (1879) defined the Ordovician System as up to 'the base of the Llandovery', and there has since been little disagreement. However, the type Llandovery is poorly fossiliferous near its base, and so Cocks, Toghill \& Ziegler (1970) proposed that the base of the Llandovery, and thus also the bases of the Silurian System and the Rhuddanian Stage, should be transferred from Llandovery (Wales) to Dob's Linn (Scotland), where Lapworth had established many of his graptolite zones, which are the most accurate correlation tools at these levels. The boundary level suggested was at the base of the persculptus Biozone near the base of the Birkhill Shale Formation, following earlier workers such as Jones \& Pugh (1935). To examine the situation in more detail, the International Commission on Stratigraphy set up in 1974 an international Ordovician-Silurian Boundary Working Group to review the most appropriate stratotype and boundary level. That group concluded that the 'Golden Spike' should be placed at Dob's Linn, but at the base of the succeeding acuminatus Biozone at $1.6 \mathrm{~m}$ above the base of the Birkhill Shale Formation [Grid reference NT 1961 1574]. This was principally so that the widespread Hirnantia brachiopod fauna and the end-Ordovician Hirnantian glacial episode should be included within the Ordovician rather than straddling the boundary across the two systems. The boundary in several sections across the world, including the stratotype, and the distributions of various fossil groups around the boundary are described in the many papers within Cocks \& Rickards (1988). More recently, the acuminatus Zone sensu lato has been subdivided into an underlying ascensus Biozone and an overlying acuminatus Zone sensu stricto, but the International Commission on Stratigraphy voted in 2007 to retain the Dob's Linn systemic boundary at the same place as previously, and indicated that the correlation of that 'Golden Spike' point was at the base of the ascensus Biozone.

\section{The Silurian System}

Murchison (1835) erected the name Silurian, but, like the Cambrian, its modern concept dates from Lapworth's founding of the Ordovician in 1879. All of the Silurian is formally correlated today by graptolite biozones. In limestone sequences, particularly in Laurentia, in which graptolites are rare or absent, conodonts have also been used, but the Silurian graptolite zones are much shorter. Since the influential correlation chart of Berry \& Boucot (1970), North Americans have employed the British nomenclature (Fig. 1), but before then the Medinan (or Alexandrian), Niagaran and Cayugan Series were used in Laurentia. Useful global Silurian correlations were published within the volume edited by Landing \& Johnson (2003). In many older publications, particularly in continental Europe, Gothlandian was used as a system name, but that was internationally abandoned in favour of Silurian in 1960. Comparably, for some years the terms Valentian and Salopian were in vogue for graptolitic sequences in Britain and elsewhere, but the former has been abandoned in favour of Llandovery and the latter was essentially equivalent to Wenlock and Ludlow combined. The terms Llandovery, Wenlock and Ludlow, together with their included stages defined in Britain noted below, have been adopted as the global standards by the International Commission on Stratigraphy (Bassett, 1985).

\section{7.a. Llandovery Series}

Cocks, Toghill \& Ziegler (1970) had divided the Llandovery into four stages: the Rhuddanian, Idwian, Fronian and Telychian, the latter three with their defined bases in the type Llandovery area of Carmarthenshire, Wales. However, those were deemed unsatisfactory by the international Silurian Subcommission, and thus, after further work in the Llandovery area, a revised scheme was devised by Cocks et al. (1984), which was subsequently voted to be the global standard (Bassett, 1985).

\section{7.a.1. Rhuddanian Stage}

See Section 6, Ordovician-Silurian boundary.

\section{7.a.2. Aeronian Stage}

This has its base in the Trefawr track section, near Llandovery (Grid reference SN 8380 3953), within the Trefawr Formation and at the base of the triangulatus 
Biozone, as proved by the graptolites occurring there (Cocks et al. 1984).

\section{7.a.3. Telychian Stage}

This also has its base in the Llandovery area, Carmarthenshire, and was originally placed by Cocks, Toghill \& Ziegler (1970) at the base of Jones' (1925) C4 subdivision (the base of the Wormwood Formation) in the Cefn Cerig Road section southeast of Llandovery. However, after the more detailed revision by Cocks et al. (1984), it was moved upwards to near the base of the overlying C5 subdivision of Jones, and the revised stratotype is near the top of the Wormwood formation in a small disused quarry close to the Cefn Cerig Road [SN 7743 3232]. The stratotype horizon represents the transition between the evolving brachiopods Eocoelia intermedia and E. curtisi, a horizon which correlates approximately with the base of the turriculatus graptolite Biozone sensu lato; the latter has now been subdivided into a lower guerichi and an upper turriculatus sensu stricto Zone (Loydell, 1992).

\section{7.b. Wenlock Series}

Bassett et al. (1975) defined two stages within the type Wenlock area of Shropshire, England, and these were accepted as the global standard (references in Holland \& Bassett, 1989).

\section{7.b.1. Sheinwoodian Stage}

The base of this stage coincides with the base of the Wenlock Series and its stratotype lies at the conformable junction between the Hughley Shale Formation and the Buildwas Formation in Harley Brook at Grid reference [SO 5688 9839], at a level which approximately correlates with the centrifugus Biozone. Although characteristic graptolites have not been found at the stratotype section itself, it has yielded abundant and stratigraphically useful microfossils, particularly acritarchs and chitinozoans (Mullins \& Aldridge, 2004).

\section{7.b.2. Homerian Stage}

The base lies within the Coalbrookdale Formation and is defined within a stream section in a small tributary to Sheinton Brook [Grid reference SO 6194 0204] at the base of the lundgreni Biozone. Bassett et al. (1975) also defined two formal chronozones within this stage, the Whitwell Chronozone, whose base coincides with the base of the Homerian, and the overlying Gleedon Chronozone, whose base is exposed in a track near Eaton Church [SO 5016 8999] at the base of the nassa Biozone; however, the International Commission on Stratigraphy decided that international correlation was not yet fine enough for such chronozones to be useful.

\section{7.c. Ludlow Series}

This term was originally coined by Murchison but was defined more precisely and split into four divisions, the Eltonian, Bringewoodian, Leintwardinian and Whitcliffian, by Holland, Lawson \& Walmsley (1963). The Silurian Subcommission decided that there were too many to be appropriate as international stages, and thus two international stage names were eventually accepted (Holland et al. 1980).

\section{7.c.1. Gorstian Stage}

The stratotype base of this stage and also the Ludlow Series is defined at an old quarry in Pitch Coppice, near Ludlow, Shropshire [Grid reference SO 4723 7298] at the conformable junction between the Much Wenlock Limestone Formation and the Elton Formation at a level which correlates with the base of the nilssoni Biozone. The stage includes the Eltonian and Bringewoodian of the former classification.

\section{7.c.2. Ludfordian Stage}

The base is at Sunnyhill Quarry, near Ludlow [SO 4950 7255] at the conformable junction between the Bringewood and Leintwardine formations at a level estimated to correlate with the base of the incipiens Biozone. The stage includes the Leintwardinian and Whitcliffian of the former classification.

\section{7.d. Pridoli Series}

The diacritical marks of the Czech 'Př́dolí' are often omitted from general publications, and we follow that practice here. Because of the relatively short duration of the series, it has not been divided into stages. Its base is within the Pozáry Formation at Pozáry, near the southwestern boundary of Prague, Czech Republic, and coincides with the base of the ultimus Biozone (Krríž et al. 1986). Through a complex correlation web in which ostracods and conodonts are important, that level essentially correlates with the base of the longestablished Downton Series of Britain, named after Downton Gorge, near Ludlow, Shropshire (White \& Lawson, 1989; Miller, 1995).

\section{The Siluro-Devonian boundary}

In 1960 the Siluro-Devonian Boundary Working Group (originally termed 'Committee') was the first such to be established, and its conclusions were internationally endorsed by the nascent International Commission on Stratigraphy in 1972. These were later summarized in Martinsson (1977), which includes many descriptions of boundary sections across the world and the distributions of key floral and faunal groups. Even Murchison (e.g. 1866) had recognized 'Passage Beds', later termed the Downton Series, above the Silurian in the Welsh Borderland and underlying the unequivocally Devonian Old Red Sandstone. For many years, most 
British stratigraphers took the base of the Devonian at the thin Ludlow Bone Bed, which lies at the very top of the Ludlow succession in the type Ludlow area, and above which the Downtonian is largely non-marine. In the late nineteenth and early twentieth centuries, graptolites were thought to have become extinct at the end of the Silurian, and thus graptolite-bearing beds were naturally considered to be Silurian in continental Europe. However, when distinctive Old Red Sandstone fish were correlated with those later 'Silurian' French, Belgian and German deposits, it became clear that graptolites had persisted through the Lower Devonian. Following much debate, the stratotype boundary was eventually agreed at $8 \mathrm{~m}$ above the base of the Lochkov Formation within the classic Barrandian sequence at Klonk, near Prague, Czech Republic, and at the base of the uniformis graptolite Biozone. A more recent borehole drilled across the boundary has documented further the graptolite and sedimentological data $(\mathrm{Ch}-$ lupàč \& Hladil, 2000). In Britain, the Downtonian is therefore at least mainly of Silurian age, although the boundary between it and the overlying Dittonian part of the Old Red Sandstone has not yet been precisely correlated with the stratotype basal Devonian section in the Czech Republic.

\section{Postcript}

Geologists have hitherto often despaired at the lack of stability and international agreement on standard correlation terms. However, despite some tension which has occurred at times during the long period of gestation while the standards outlined above have been formulated and agreed, that period seems happily now nearly over, and we can hope that the schemes here will be of permanent use in industrial as well as academic applications.

Acknowledgements. We are very grateful to numerous colleagues in Britain and abroad for discussion, particularly those who have served with us on the Cambrian, Ordovician and Silurian Subcommissions, and also the members of the Ludlow Research Group. Charles Holland merits special acclaim for his adroit steering of the Silurian subdivisions. We thank Abigail Brown for drafting the figure, and Jan Zalasiewicz and two anonymous referees for comments.

\section{References}

Babcock, L. E., Peng, S. C., Geyer, G. \& Shergold, J. H. 2005. Changing perspectives on Cambrian chronostratigraphy and progress toward subdivision of the Cambrian System. Geosciences Journal 9, 101-6.

BAbcock, L. E., Robison, R. A., Rees, M. N., Peng, S. C. \& Saltzman, M. R. 2007. The global boundary stratotype section and point (GSSP) of the Drumian Stage (Cambrian) in the Drum Mountains, Utah, USA. Episodes 30(2), 85-95.

BASSETT, M. G. 1985. Towards a 'common language' in stratigraphy. Episodes 8, 87-92.

Bassett, M. G., Cocks, L. R. M., Holland, C. H., RickARDS, R. B. \& WARrEN, P. T. 1975. The type
Wenlock Series. Institute of Geological Sciences Report 75/13, 1-19.

Bergström, S. M., Finney, S. C., Xu, C., PÅlsson, C., WANG, Z. \& GRAHN, Y. 2000. A proposed global boundary stratotype for the base of the Upper Series of the Ordovician System: the Fågelsång section, Scania, southern Sweden. Episodes 23, 102-9.

Bergström, S. M., LöFgren, A. \& Maletz, G. 2004. The GSSP of the Second (Upper) Stage of the Lower Ordovician series. Episodes 27, 265-72.

Berry, W. B. N. \& Boucot, A. J. 1970. Correlation of the North American Silurian rocks. Geological Society of America Special Paper 102, 1-289.

BetTley, R. M., ForTeY, R. A. \& SiVETER, D. J. 2001. Highresolution correlation of Anglo-Welsh Middle to Upper Ordovician sequences and its relevance to international chronostratigraphy. Journal of the Geological Society, London 158, 937-52.

Brasier, M. D., Cowie, J. W. \& Taylor, M. E. 1994. Decision on the Precambrian-Cambrian boundary stratotype. Episodes 17, 3-8.

Chen, X. \& Bergström, S. M. (eds) 1995. The base of the austrodentatus Zone as a level for global subdivision of the Ordovician System. Palaeoworld 5, 1117.

CHLUPÀČ, I. \& HLADIL, J. 2000. The global stratotype section and point of the Silurian-Devonian boundary. Courier Forschungsinstitut Senckenberg 225, 1-7.

Cocks, L. R. M., Holland, C. H., \& RickARDS, R. B. 1992. A revised correlation of Silurian rocks in the British Isles. Geological Society, London, Special Report 21, $1-32$.

Cocks, L. R. M., Holland, C. H., Rickards, R. B. \& STRACHAN, I. 1971. A correlation of Silurian rocks in the British Isles. Journal of the Geological Society, London 127, 103-36.

Cocks, L. R. M. \& Rickards, R. B. (eds) 1988. A global analysis of the Ordovician-Silurian boundary. Bulletin of the British Museum (Natural History) Geology 43, $1-394$.

Cocks, L. R. M., Toghill, P. \& Ziegler, A. M. 1970. Stage names within the Llandovery series. Geological Magazine 107, 79-87.

Cocks, L. R. M., WoOdCOCK, N. H., Rickards, R. B., TEMPLE, J. T. \& LANE, P. D. 1984. The Llandovery Series of the type area. Bulletin of the British Museum (Natural History) Geology 38, 131-82.

Cooper, A. H., Fortey, N. J., Hughes, R. A., Molyneux, S. G., Moore, R. M., Rushton, A. W. A. \& Stone, P. 2004. The Skiddaw Group of the English Lake District. British Geological Survey, Memoir, 1-147 (issued 2005).

CoOPer, M. R., Crowley, Q. G. \& Rushton, A. W. A. 2008. New age constraints for the Ordovician Tyrone Volcanic group, Northern Ireland. Journal of the Geological Society, London 165, 333-9.

Cowie, J. W., Rushton, A. W. A. \& Stubblefield, C. J. 1972. A correlation of Cambrian rocks in the British Isles. Geological Society, London, Special Report 2, 142.

ELLES, G. L. 1922. The graptolite faunas of the British Isles: a study in evolution. Proceedings of the Geologists' Association 33, 168-200.

FleTCHeR, T. P. 2006. Bedrock geology of the Cape St Mary's Peninsula, southwest Avalon Peninsula, Newfoundland. Government of Newfoundland and Labrador, Geological Survey, Department of Natural Resources, St John's, Report 06-02. 
Fortey, R. A., Harper, D. A. T., Ingham, J. K., Owen, A. W., Parkes, M. A., Rushton, A. W. A. \& WoODCOCK, N. H. 2000. A revised correlation of Ordovician rocks in the British Isles. Geological Society, London, Special Report 24, 1-83.

Fortey, R. A., Harper, D. A. T., Ingham, J. K., Owen, A. W. \& Rushton, A. W. A. 1995. A revision of the Ordovician series and stages from the historical type area. Geological Magazine 132, 15-30.

Fortey, R. A. \& OwENS, R. M. 1987. The Arenig Series in South Wales. Bulletin of the British Museum (Natural History) Geology 41, 69-307.

GeYER, G. 2005. The base of the Middle Cambrian: are suitable concepts for a series boundary in reach? Geosciences Journal 9, 81-99.

Goldman, D., Leslie, S. A., Nõlvak, J., Young, S., Bergström, S. M. \& HufF, W. D. 2007. The global stratotype section and point (GSSP) for the base of the Katian stage of the Upper Ordovician Series at Black Knob Ridge, southeastern Oklahoma. Episodes 30, 25870.

Grotzinger, J. P., Bowring, S. A., SAYLOR, B. Z. \& KAUFMAN, A. J. 1995. Biostratigraphic and geochronologic constraints on early animal evolution. Science $\mathbf{2 7 0}$, 598-604.

Harland, W. B., Armstrong, R. L., Cox, A. V., Craig, L. E., Smith, A. G. \& SMith, D. G. 1990. A Geologic Time Scale 1989. Cambridge University Press.

Holland, C. H. \& Bassett, M. G. (eds) 1989. A global standard for the Silurian System. National Museum of Wales Geological Series 9, 1-325.

Holland, C. H., LaWson, J. D. \& Walmsley, V. G. 1963. The Silurian rocks of the Ludlow district, Shropshire. Bulletin of the British Museum (Natural History) Geology 8, 93-171.

Holland, C. H., LAWSON, J. D., WALMSLEy, V. G. \& White, D. E. 1980. Ludlow stages. Lethaia 13, 268.

Howells, M. F. \& SMITH, M. 1997. Geology of the country around Snowdon. Memoir of the British Geological Survey, Sheet 119 (England and Wales), x + 104 pp. London: The Stationery Office.

JONES, O. T. 1925. The geology of the Llandovery District: Part I. The southern area. Quarterly Journal of the Geological Society of London 81, 344-88.

JONES, O. T. \& PUGH, W. J. 1935. The geology of the districts around Machynlleth and Aberystwyth. Proceedings of the Geologists' Association 46, 247-300.

KŘÍŽ, J., JAEGER, H., PARIS, F. \& SCHÖNLAUB, H. P. 1986. Prídolí - the fourth subdivision of the Silurian. Jahrbuch der Geologischen Bundesanstalt 129, 291-360.

LANDING, E., BOWRING, S. A., DAVIDEK, K. L., RUSHTON, A. W. A., Fortey, R. A. \& Wimbledon, W. A. P. 2000. Cambrian-Ordovician boundary age and duration of the lowest Ordovician Tremadoc Series based on $\mathrm{U}-\mathrm{Pb}$ zircon dates from Avalonian Wales. Geological Magazine 137, 485-94.

LANDING, E. \& JoHnson, M. E. (eds) 2003. Silurian lands and seas. New York State Museum Bulletin 493, 1400.

LANDING, E., PENG, S., BABCOCK, L. E. \& MocZYdŁOWSKAVIDAL, M. 2007. Global standard names for the lowermost Cambrian series and stages. Episodes 30, 287-9.

LAPWORTH, C. 1879. On the tripartite classification of the Lower Palaeozoic rocks. Geological Magazine 6, 1-15.

LOYDELL, D. K. 1992. Upper Aeronian and Lower Telychian (Llandovery) graptolites from western mid-Wales, Part 1. Palaeontographical Society Monograph 146, 1-55.
Martinsson, A. (ed.) 1977. The Silurian-Devonian Boundary. Stuttgart: Schweizerbart'sche, 349 pp.

MCILroy, D., Brasier, M. D. \& Moseley, J. B. 1998. The Proterozoic-Cambrian transition within the 'Charnian Supergroup' of central England and the antiquity of the Ediacara fauna. Journal of the Geological Society, London 155, 401-11.

MILLER, G. C. 1995. Ostracode and conodont distribution across the Ludlow/Prídolí boundary of Wales and the Welsh Borderland. Palaeontology 38, 341-84.

Miller, J. F., Evans, K. R., LOCh, J. D., Ethington, R. L., Stitt, J. H., Holmer, L. \& Popov, L. E. 2003. Stratigraphy of the Sauk III Interval (CambrianOrdovician) in the Ibex area, western Millard County, Utah and central Texas. Brigham Young University Geology Studies 47, 23-118.

MolyneuX, S. G., Raevskaya, E. \& Servais, T. 2007. The messaoudensis-trifidum acritarch assemblage and the correlation of the base of Ordovician Stage 2 (Floian). Geological Magazine 144, 143-56.

Mullins, G. L. \& AldRIDGE, R. J. 2004. Chitizonoan biostratigraphy of the basal Wenlock Series (Silurian) global stratotype and point. Palaeontology 47, 745-73.

MurChISON, R. I. 1835. The Silurian System. London and Edinburgh Philosophical Magazine 7, 46.

MURCHISON, R. I. 1866. Observations on the classification of the Silurian rocks. Palaeontographical Society Monograph, 19-31.

NARBOnNe, G. M., Myrow, P., LANDing, E. \& ANDERSON, M. M. 1987. A candidate stratotype for the Precambrian-Cambrian boundary, Fortune Head, Burrin Peninsula, southeastern Newfoundland. Canadian Journal of Earth Sciences 24, 1277-93.

NiElSEN, A. T. 2004. Ordovician sea level changes: a Baltoscandian perspective. In The Great Ordovician biodiversification event (eds B. D. Webby, F. Paris, M. L. Droser \& I. G. Percival), pp. 84-96. New York: Columbia University Press.

OrŁoWSKI, S. 1992. Cambrian stratigraphy and stage subdivision in the Holy Cross Mountains, Poland. Geological Magazine 129, 471-4.

PAlmer, A. R. 1998. A proposed nomenclature for stages and series for the Cambrian of Laurentia. Canadian Journal of Earth Sciences 35, 3323-8.

Peng, S. C., BABCOCK, L. E., Lin, H., Chen, Y. \& Zhu, X. 2004a. Global standard stratotype-section and point for the Paibian Stage and Furongian Series of the Upper Cambrian. Journal of Stratigraphy 28, 104-13.

Peng, S. C., BABCOCK, L. E., RoBison, R. A., Lin, H., REES, M. N. \& SALTZMAN, M. R. 2004b. Global standard stratotype-section and point for the Paibian Stage and Furongian Series (Upper Cambrian). Lethaia 37, 36579.

Rodgers, J. (ed.) 1956. El Sistema Càmbrico, su palaeogeografia y el problema de su base. Parts I and II. International Geological Congress, XX Session, Mexico, 1956.

Ross, R. J., Hintze, L. E., Ethington, R. L., Miller, J. F., TAYLOR, M. E. \& REPETSKI, J. E. 1997. The Ibexian, lowermost series in the North American Ordovician. United States Geological Survey Professional Papers 1579, $1-50$.

RUSHTON, A. W. A. 1982. The biostratigraphy and correlation of the Merioneth-Tremadoc boundary in North Wales. National Museum of Wales Geological Series 3, 41-59.

Rushton, A. W. A. 1983. Trilobites from the Upper Cambrian Olenus Zone in Central England. Special Papers in Palaeontology 30, 107-39, pls 14-19. 
SAdler, P. M., CoOPer, R. A. \& Melchin, M. 2009. Highresolution, early Paleozoic (Ordovician-Silurian) time scales. Geological Society of America Bulletin 121, 887906.

SEDGwick, A. \& Murchison, R. I. 1835. On the Cambrian and Silurian systems, exhibiting the order in which the older sedimentary strata succeed each other in England and Wales. The London and Edinburgh Philosophical Magazine and Journal of Science 7, 483-5.

Stouge, S., Wang, X., LI, Z., Chen, X. \& WAng, C. 2008. The base of the Middle Ordovician Series using graphical correlation method. Episodes 31, 219-28.

Wang, X., Stouge, S., Erdtmann, B. D., Chen, X., Li, Z., WANG, C., ZENG, Q., ZHou, Z. \& Chen, H. 2005. A proposed GSSP for the base of the Middle Ordovician Series: the Huanghuachang section, Yichang, China. Episodes 28, 105-17.

White, D. E. \& Lawson, J. D. 1989. The Přídolí Series in the Welsh Borderland and south-central Wales. National Museum of Wales Geological Series 9, 131-41.

Williams, A., Strachan, I., BASSETt, D. A., DEAN, W. T., Ingham, J. K., Wright, A. D. \& WhitTington, H. B. 1972. A correlation of Ordovician rocks in the British Isles. Geological Society of London, Special Report 3, $1-74$.

Zalasiewicz, J. A., Rushton, A. W. A. \& Owen, A. W. 1995. Late Caradoc graptolitic faunal gradients across the Iapetus Ocean. Geological Magazine 132, 611-17. 